\title{
UTILIZATION OF INSTAGRAM SOCIAL MEDIA BY ACCOUNT @tamanwisatagenilagit AS A PROMOTION MEDIA IN INCREASING VISITORS 'INTEREST OF TAMAN GENI LANGIT
}

\author{
Fauzia Mafiroh \\ Institut Agama Islam Negeri Ponorogo \\ Jl. Puspita Jaya, Jenangan Ponorogo
}

Abstrak: Geni Langit Tourism Park is a tourist spot located in one of Magetan regencies. This tourist park offers natural scenery combined with photo spots that make this park visited by many tourists. From the description above, the researcher is interested in conducting research on the use of Instagram social media by Geni Langit Tourism Park. This study uses a descriptive type of research with a qualitative approach, namely by describing how the use of Instagram social media by the @tamanwisatagenilangit account in increasing visitor interest. Researchers got data from observations, interviews and documentation. From the research results, conclusions can be drawn: first, the use of Instagram social media by the @tamanwisatagenilangit account is to use several Instagram features, including (1) photo title or caption, (2) Hashtag, (3) Comments (4) Mentions (5) Geotag . Second, based on the results of observations and interviews with several visitors, Instagram social media is quite effective in increasing visitor interest. This is evidenced by the statement of visitors who know the many photo posts with the Instagramable concept from the @tamanwisatagenilangit account.

\section{Keywords: Use of Instagram, Promotion, Visitor Interest}

\section{INTRODUCTION}

Tourism is an asset to a very important area. Tourism is also an attraction for local and foreign tourists. Magetan Regency is one of the areas in East Java that has a wellknown tourism potential, namely the Geni Langit Tourism Park.

Its existence is starting to be recognized by the community, both from the Magetan district and surrounding districts. The existence of social media makes it very easy for users to introduce, promote, and influence audiences with photos and videos posted by marketers or managers of a company. Besides being able to promote products easily and more economically, social media users can also access these posts at any time. One of the social media used is Instagram.

Instagram can be called media sharing. This social media facilitates its users to share media ranging from documents, video, audio, images, and so on. ${ }^{1}$ Social media Instagram is a medium that is still in great demand by its users because it makes it

\footnotetext{
${ }^{1}$ Rulli, Nasrullah, Media Sosial Perspektif Komunikasi, Budaya, dan Sosioteknologi (Bandung:

Simbiosa Rekatama Media, 2015), 44.
} 
easier for users to upload photos, short videos, which can be accompanied by a description below, can be referred to as "captions". Therefore, Instagram is a tool for promotion. Instagram accounts that have been followed by users, can immediately comment under photos or videos. To introduce and increase the interest of visitors to the tourist park, the manager uses advertising media to promote it. Of the many advertising and social media media, Instagram is the choice of the @tamanwisatagenilangit account as a means of promoting the Geni Langit Tourism Park in Magetan Regency. Based on the researcher's experience after conducting interviews with several visitors, many visitors know and are interested in the tourist park through Instagram social media. Therefore, researchers are interested in researching the use of Instagram social media as a promotional medium in increasing the interest of visitors to the Geni Langit Tourism Park.

This research uses a descriptive type of research with a qualitative approach. Descriptive method is intended for exploration and clarification of a social phenomenon or reality, by describing a number of variables relating to the problem and unit under study. ${ }^{2}$ Qualitative research aims to gain a general understanding of social reality from the perspective of participants. This understanding is not determined in advance but is obtained after analyzing the social realities which are the focus of the research and then a conclusion is drawn in the form of a general understanding of these facts. ${ }^{3}$ The author uses a qualitative descriptive approach because the author wants to describe the results of the study using written words and describe the results of the interview from the research object.

\section{UTILIZATION OF INSTAGRAM SOCIAL MEDIA AS A PROMOTIONAL MEDIA}

In promoting the charm of the beauty of Geni Langit Tourism Park to the public using Instagram, managers need several Instagram features that can help with promotional activities. Instagram is a social media that prioritizes content in the form of images over text, so Instagram is very suitable to be used in promoting Geni Langit Tourism Park which has an Instagramable tourism concept. The form of using Instagram that is carried out by the management of the Geni Langit Tourism Park in promoting the tourist park is by using Instagram features. The use of this feature is useful for supporting the content of the Geni Langit Tourism Park account by the initial concept of establishing this tourist park, namely the Instagramable concept. The things that are done by the management of Geni Langit Tourism Park for promotional activities are as described by the researcher. Following are the steps were taken by the management of the Geni Langit Tourism Park in promotional activities using the three Diamond Rule theory:

\section{Conten}

\footnotetext{
${ }^{2}$ H. Ardial, Paradigma dan Model Penelitian Komunikasi (Jakarta: Bumi Aksara, 2015), 262.

${ }^{3}$ Rosady Ruslan, Metode Penelitian Public Relations dan Komunikasi (Jakarta: PT Rajagrafindo Persada, 2010), 215.
} 
In the world of Instagram, content is still the main thing. The content in question is an image or video. That's the reason why Instagram images are placed on top of the text. The essence of content is to make followers feel close to the content creator. The images presented by @tamanwitagenilangit are mountains, flying fox, all-terrain vehicle (ATV), swimming pool, and outbound rides that are identical to the outdoor atmosphere.

a. Number of posts Content

So after successfully creating Instagram content, Instagram account users must pay attention to the number of posts each day. Because if you post too many photos (content spamming), the followers will feel annoyed and they will unfollow. The maximum number of posts that are safe and acceptable to followers is 3 in a day. The process of posting on Instagram social media on the@tamanwiatagenilangit account is carried out twice a week. It has become a routine schedule for the management of Geni Langit Park.

b. Instagram stories

This feature is very important in the world of social media. The concept of stories is the creation of social media content that is different from creating ordinary content. Stories are more "now" so they have a time limit to appear. ${ }^{4}$ Stories have added to the way Instagram users enjoy the content. Stories content will continue to the next content without having to interact with buttons or scrolls.

c. Hashtag

Hashtags are a feature of Instagram that can help users to promote. In this case, Geni Langit Tourism Park has created a special hashtag that can later be used by managers and followers when posting photos, namely \#tamanwisatagenilanit. By using this hashtag, visitors who want to post their photos can be immediately seen by the manager of the Geni Langit Tourism Park Instagram account. The advantages of using hashtags are that content is easier to find, there is an opportunity to enter the top posts, and provides an overview of Instagram content categories that users create.

\section{Consistency}

Consistency is the oldest trick in business books, which can subconsciously influence a person's expectations. Some consistencies that must be considered are the consistency of time, consistency of values, consistency of image quality, and consistency of themes (color layout and other visual matters). The consistency of posts must also be considered by the Taman Wisata Geni Langit account manager so that followers have expectations to see the content posted. Posting consistency has been carried out by the Taman Wisata Geni Langit account manager. By

\footnotetext{
${ }^{4}$ Mattew Sugiarto, Instagram Marketing (Jakarta Selatan, PT. Pengembang Lintas Pengetahuan: 2018), 76.
} 
posting photos every week, posting twice, and held at break times such as noon. Posting content consistently will accelerate penetration to reach the top posts. Top posts with many users will always change every day, so they are required to compete with all users of the hashtag.

\section{Community}

A community must be the main goal of managing an Instagram account. In all businesses it is meaningless if the product offered does not have a community. The advantage of having a community is that marketing products is much easier, increases the level of follower trust, it is easier to understand the needs of the community further. According to researchers' observations, Geni Langit Tourism Park already has an adequate community. In addition to establishing relationships with social media admins, Ali Muhtar as the manager of the @tamanwisatagenilangit account also explained that many visitors post their shots on Instagram by including geotagging (location) and hashtags such as those made by the Taan Wisata Geni Langit account manager.

According to the researchers' observations, based on the data obtained in the field and related to the theory presented by the researcher, Instagram social media is quite effective in helping promotional activities at Geni Langit Tourism Park. With the sophistication of Instagram, such as being easy to understand, 24 hour broadcast time, easy to use, and easy to convey new things, because the focus of content on Instagram is Instagram images also have many advanced features that can help with the promotion of Taman Wisata Geni Langit. In addition to the advanced features that Instagram has, by maximizing the use of these features, promotional activities will run smoothly.

The following features are used by Geni Langit Park:

1. Photo title or caption

In terms of promotion, this caption is intended to inform and influence the public about the beauty of the Geni Langit Tourism Park, so that the public will know and be interested in visiting the Geni Langit Tourism Park. Therefore, the caption must be made as attractive as possible so that it has a positive influence on the audience and is interested in visiting Geni Langit Tourism Park.

2. Hashtags

According to the researchers' observations, based on the existing findings in the field, and linked to the theory described in the previous chapter, the management of Geni Langit Park has maximized the use of hashtags by forming an official hashtag by the manager, namely \#tamanwisatagenilangit. The following is an example of using hashtags on the @tamanwisatagenilangit account created by the manager. 


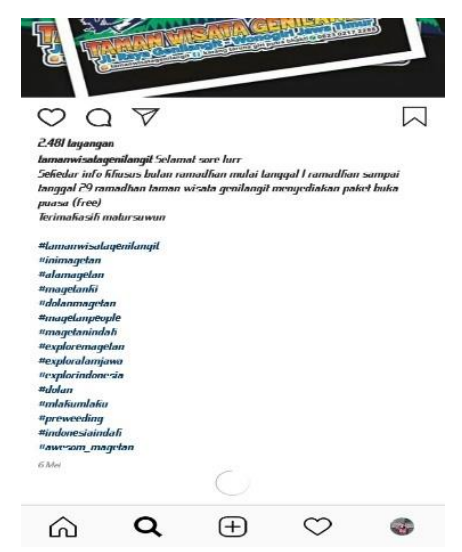

Figure 4.2 Use of Hashtags on Social Media Posts of Geni Langit Park

3. Geotag (location)

The addition of locations or geotags also does not forget to include the manager in their posts. Geotags also help visitors find the existence of Geni Langit Tourism Park more easily.

Adding geotags can be done by activating GPS permissions on smartphones for the Instagram application, to find location options when posting content. By adding a tag to each post, the existence of Geni Langit Park will be better known by the wider community. According to the researchers' observations, many visitors to the Geni Langit Tourism Park include geotags in each of their posts. This is evidenced by the number of posts that enter the profile of the Geni Langit Tourism Park as follows:

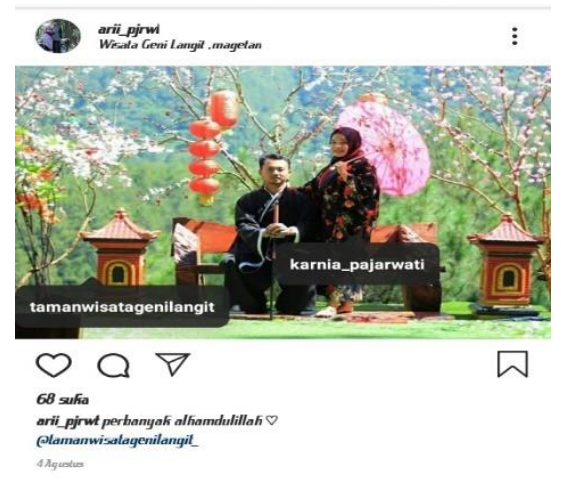

\section{$\circlearrowleft \quad 9 \quad \oplus \quad 0$ 웅}

Figure 4.3 Geotag feature usage in Geni Langit Park Visitor Posts 


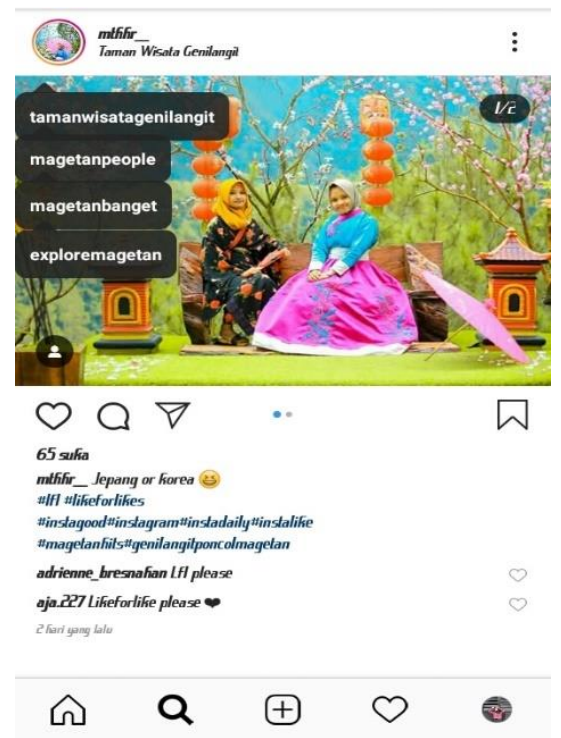

Figure 4.4 Use of the Geotag feature in Geni Langit Park Visitor Posts

Among Instagram activities that can be done:

1. Follow

The Instagram account for Taman Wisata Geni Langit was created by Ali Muhtar in November 2016. At this time the followers of the @tamanwisatagelangit account have reached 140,500 thousand followers with 554 posts including photos and videos. This shows that the popularity of Geni Langit Park is well known by many people. Visitor interest is expected to increase along with the ongoing development of the Geni Langit Tourism Park. Because according to information from Edi Soko Cahyono as the head of the management, he said that the construction of the Geni Langit Tourism Park is still $30 \%$ to $35 \%$.

According to researchers' observations, in addition to the many followers on the Taman Wisata Geni Langit Instagram account, the manager has also followed several accounts that have posted and included hashtags on Taman Wisata Geni Langit. Then the manager reposts or reposts the photo. Thus visitors will feel appreciated and foster interest in visiting Geni Langit Tourism Park again. This also benefits both parties. Taman Wisata Geni Langit has many photos to be posted on the Instagram account of Taman Wisata Geni Langit, as well as photos that are reposted, users will get additional followers after the photos are reposted. By Ali Muhtar's statement,

"If we look at the followers of the account from visitors, if there are already a lot of followers then we can follow back. So if these visitors post pictures, many will see the post and are interested in visiting the Geni Langit Tourism Park" 5 
2. Like

Like is an icon where users can like images or photos on Instagram. With this feature, every visitor who has followed the @tamanwisatagenilangit account and likes photo posts can immediately press the like button. The more likes the Geni Langit Tourism Park gets, the more it shows that Geni Langit Tourism Park has many enthusiasts. The manager of Geni Langit Tourism Park will provide a like button for unique photos that meet the criteria set by the Geni Langit Tourism Park. Namely, the photo looks attractive, the photo looks clear and polite.

The criteria for photos that will be liked are conveyed by the manager of the Geni Langit Tourism Park,

"Usually, many visitors upload their photos. Then if the uploaded photo is good and polite, we will like the photo." 6

\section{Comments}

In the comments column, users are free to comment on photos, be it suggestions, praise, or criticism through words. There are many kinds of comments written in the @tamanwisatagenilangit comments column. If the comment contains a positive element, the manager will reply to it with a positive comment too. Vice versa with negative comments, the manager will leave the comments.

\section{Mentions}

By adding an arroba sign (@) in the comments column and entering the Instagram account of the user you want to add, it will help promotional activities. According to researchers' observations, this Instagram feature is most often used by managers and visitors to add other users and then invite other users to visit Geni Langit Park. Thus, Geni Langit Tourism Park will increasingly experience an increase in visitors without having to carry out direct promotions with visitors.

The presence of social media, especially Instagram, is a distinct advantage for Geni Langit Tourism Park, to promote this tourist park in a relatively short time and does not require a fairly expensive fee. The management of Geni Langit Park is also able to reach audiences from various regions, by utilizing the features provided by Instagram. So that the Geni Langit Tourism Park will be better known by the wider community, not limited to the Magetan area and its surroundings. 


\section{THE EFFECTIVENESS OF INSTAGRAM PROBLEMS IN IMPROVING VISITORS 'INTEREST}

In promotional activities carried out on social media properly, it will generate interest for content connoisseurs to visit the places, goods, or services offered. Likewise, Geni Langit Tourism Park tries to display good quality photos. To increase visitor interest, managers take advantage of Instagram features that can help the process of promotional activities.Because images are visual or emphasize images rather than text, the communication process to convey new products and unique concepts will be understood more quickly. Plus the Indonesian people have a very high level of curiosity about something new. Based on the stages of consumer purchase interest, or visitor interest in Geni Langit Tourism Park, conclusions can be drawn: First, attention. At this stage, prospective tourists have an interest in Geni Langit Tourism Park with proven recognition from several visitors who know the image posts on Instagram of Geni Langit Tourism Park, then potential visitors begin to follow the account. Second, be interested. Prospective visitors to the Geni Langit Tourism Park are starting to be interested in visiting the tourist park. Evidenced by the action of inviting visitors to other Instagram users to visit the Geni Langit Tourism Park.

Third, desire. Prospective visitors have thought and have a strong desire to visit the tourist park by marking some of the friends they want to invite to Geni Langit Tourism Park. Fourth, action. At this stage, visitors take action, namely by visiting the Geni Langit Tourism Park. To prove a sense of curiosity or a sense of interest in this Geni Langit Tourism Park. From the description above, it can be concluded that the presence of Instagram social media is quite effective in increasing visitor interest. Because the features that Instagram has been very helpful for managers in promotional activities for Geni Langit Park. Evidenced by the statement of visitors who know a lot about this Geni Langit Tourism Park through posting pictures on Instagram, Geni Langit Tourism Park.

\section{CONCLUSSION}

Based on the research in the article "Utilization of Instagram Social Media by @tamanwisatagenilangit Account as Promotional Media in Increasing Visitor Interest of Geni Langit Park" it can be concluded that the research results are: first, the use of Instagram social media by Taman Wisata Geni Langit through the @tamanwisatagenilangit account is shown by utilizing Instagram features that have been described by researchers such as titles or captions, hashtags, comments, mentions, and geotags. And the use of the three Diamond Rule method has also been applied even though the results are not optimal. Second, based on data obtained by researchers in the field through observation, interviewing and documentation, Instagram social media is quite effective as a promotional medium in reaching many visitors. Evidenced by the statement of visitors who know a lot about this Geni 
Langit Tourism Park through posting pictures on Instagram, Taman Wisata Geni Langit.

This article can be used as learning material or additional reference for academics in the same field, namely Communication Science regarding the Use of Instagram social media, especially for Islamic Communication and Broadcasting students. And the results of this study can be input or reference material for managers of Geni Langit Tourism Park to maximize the process of promotional activities using social media, especially Instagram.

\section{REFERENCES}

Alma, Buchari. Manajemen Pemasaran dan Pemasaran Jasa. Bandung: Alfabeta. 2018

Ardial, H. Paradigma dan Model Penelitian Komunikasi. Jakarta: Bumi Aksara. 2015.

Atmoko, D Bambang. Instagram Handbook . Jakarta: Media Kita. 2018.

Banjarsari, Yudhi Gumbiro. "Pemanfaatan Instagram Seabagai Media Komunikasi

Pemasaran Online Page Down Cloth Maker". Skripsi. Universitas Muhammadiyah Surakarta: 2018.

Basrowi. Memahami Penelitian Kualitatif. Jakarta: Rineka Cipta. 2008.

Ghony, M. Djunaidi dan Fauzan Almanshur. Metode Penelitian Kualitatif. Yogyakarta: Ar-Ruzz Media. 2012.

Kasmit. Pemasaran Bank. Jakarta: Prenada Media. 2004.

Kriyantono, Rachmat. Teori Public Relations Perspektif Barat dan Lokal: Aplikasi

Penelitian dan Praktik. Jakarta: Prenadamedia Group. 2014.

Mahmud. Metode Penelitian Pendidikan. Bandung: CV Pustaka Setia. 2011.

Nasrullah, Rulli. Media Sosial Perspektif Komunikasi, Budaya, Dan Sosioteknologi. Bandung: Simbiosa Rekatama Media. 2015.

Nawawi, Hadari. Metode Penelitian Bidang Sosial. Yogyakarta: Gadjah Mada University Press. 2007.

Nugrahani, Farida. Metode Penelitian Kualitatif dalam Penelitian Pendidikan Bahasa. Surakarta: 2014.

Permatasari, Gita. “Efektivitas Media Sosial Instagram Sebagai Media Promosi Produk Olahan Pertanian "Yoghurt Cimory". Skripsi. Institut Pertanian Bogor: 2016.

Priansa, Juni Donni. Perilaku Konsumen Dalam Persaingan Bisnis Kontemporer. Bandung: Alfabeta. 2017.

Raco, J. R. Metode Penelitian Kualitatif: Jenis, Karakteristik dan Keunggulannya. Jakarta: PT Grasindo. 2010.

Ramadhan, Harisa Fadli. “Pemanfaatan Media osial Instagram @MR. CREAMPUFF Sebagai Promosi Dalam Meningkatkan Penjualan". Skripsi. Universitas Riau: 2017.

Ruslan, Rosady. Metode Penelitian Public Relations dan Komunikasi. (Jakarta: PT Rajagrafindo Persada. 2010.

Simandjuntak, John P. dkk. Public Relations. Yogyakarta: Graha llmu, 2003. 
Sugiarto, Matthew. Instagram Marketing. Jakarta Selatan, PT. Pengembang Lintas Pengetahuan. 2018

Sugiyono. Metode Penelitian Pendidikan. Bandung: Alfabeta. 2012.

Sunyoto, Danang. Strategi Pemasaran, Yogyakarta: PT Buku Seru. 2015. 